\title{
An eight kilogram chunk and more: evidence for a new class of iron silicide meteorites from the Chiemgau impact strewn field (SE Germany)
}

\author{
F. Bauer ${ }^{1}$, M. Hiltt' ${ }^{2}$, M. A. Rappenglück ${ }^{3}$, K. Ernstson ${ }^{4}$ \\ 1 Oxford Instruments GmbH NanoScience, Wiesbaden, Germany; frank.bauer @oxinst.com \\ ${ }^{2}$ Carl Zeiss Microscopy GmbH, D-73447 Oberkochen, Germany; mhiltl@online.de \\ 3 Institute for Interdisciplinary Studies, D-82205 Gilching, Germany; mr@infis.org \\ ${ }^{4}$ University of Würzburg, D-97074 Würzburg, Germany; kernstson@ernstson.de
}

Introduction

The find of a big $8 \mathrm{~kg}$ weighting iron silicide chunk (Fig. 1) found about 30 years ago in the Chiemgau meteorite impact strewn field (Fig. 1) [1-3 and references therein] has strongly supported the earlier formulated hypothesis [ $1-3$ and references therein] of an extraterrestrial origin for the abundant occurrences of iron silicides
(Fig. 2) in connection with the craters in the elliptically formed strewn field sized about $60 \times 30 \mathrm{~km}$ [1]. Up to now some thousands of iron silicide particles have been sampled, mostly by metal detectors, roughly amounting to a mass of a few kilograms (apart from the $8 \mathrm{~kg}$ chunk). Here we report on new analyses, which establish an obviously common formation and origin.
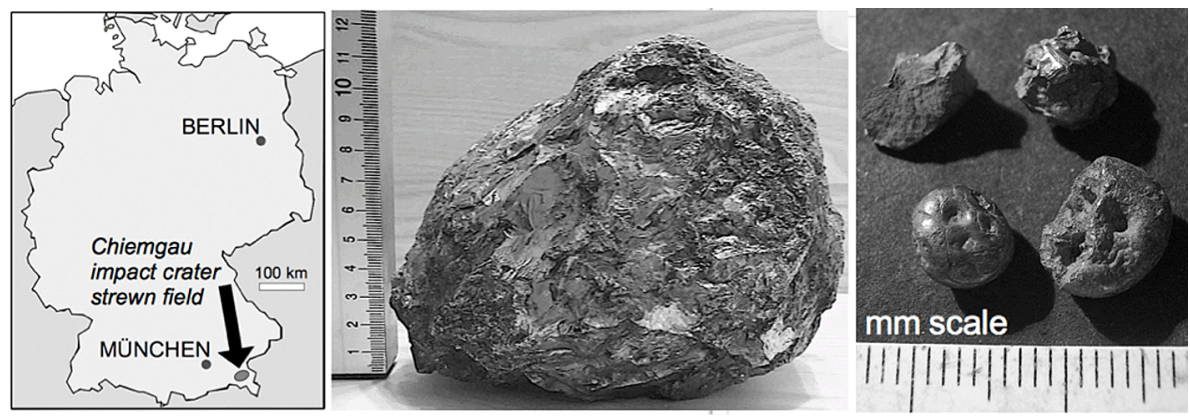

Fig. 1. Location map for the Chiemgau impact crater strewn field. Middle, right: Iron silicide finds addressed analytically in this paper
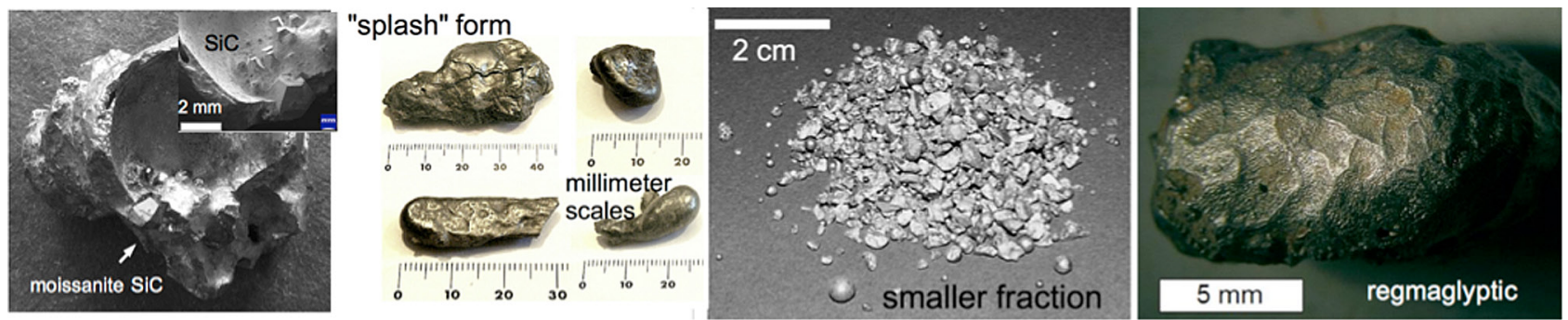

Fig. 2. Various aspects (apart from Fig. 1) of the iron silicide finds from the Chiemgau impact strewn field 

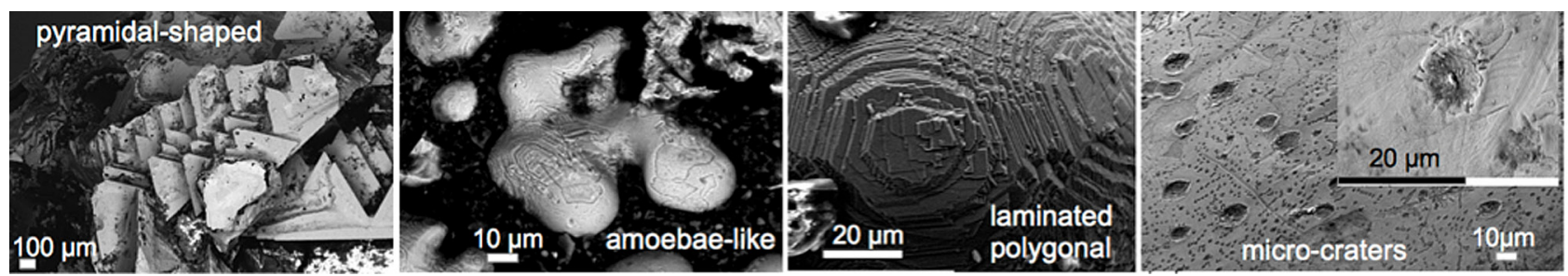

Fig. 3. Internal structure of iron silicides from the Chiemgau strewn field under the SEM
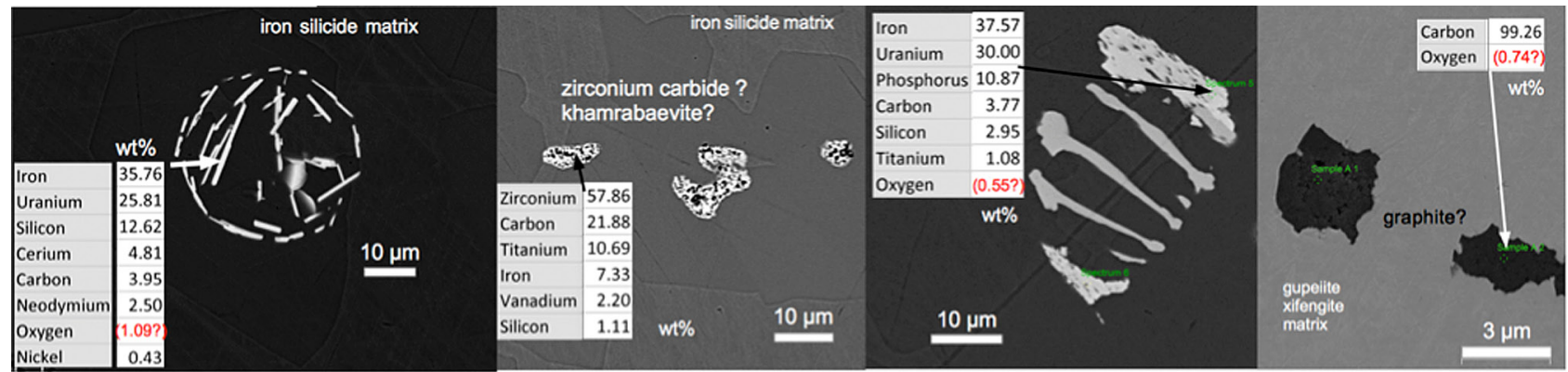

Fig. 4. SEM-EDS micrographs and analyses; samples from Fig. 1, right. Quite comparable analyses have been made in the $8 \mathrm{~kg}$ iron silicide chunk (Fig. 1) [3] and in earlier analyses of various finds

\section{Methods and results}

Optical microscopy, SEM, TEM and EBSD analyses, Raman spectroscopy.

Elements: Apart from the main constituents Fe, Si more than 30 other chemical elements have been evidenced so far like uranium, the REE cerium, yttrium und ytterbium, or gallium. No decay products of uranium like thorium or lead have been measured.

Iron silicide minerals of the matrix: gupeiite, xifengite, hapkeite, naquite and linzhite; hapkeite $\mathrm{Fe}_{2} \mathrm{Si}$ in its cubic polymorph and in its trigonal polymorph (the most stable iron silicide up to $255 \mathrm{GPa}$ ).

Identified minerals: Carbides - silicon carbide moissanite SiC (cubic and hexagonal polymorphs), titanium carbide $\mathrm{TiC}$, khamrabaevite $(\mathrm{Ti}, \mathrm{V}, \mathrm{Fe}) \mathrm{C}$, probably zirconium carbide ZrC (Fig. 4) - Graphite $\mathrm{C}$, zircon $\mathrm{ZrSiO}_{4}$; Carbon and $\mathrm{TiC} /(\mathrm{Ti}, \mathrm{V}, \mathrm{Fe}) \mathrm{C}$ in a matrix of cubic hapkeite and cubic gupeiite; $\mathrm{SiC}$ and $\mathrm{TiC} /(\mathrm{Ti}, \mathrm{V}, \mathrm{Fe}) \mathrm{C}$ as superpure crystals in the iron silicide matrix (Fig. 2). - Calcium-aluminum inclusion (CAI) minerals $\mathrm{CaAl}_{2} \mathrm{O}_{4}$, calcium monoaluminate, krotite, and $\mathrm{Ca}_{2} \mathrm{Al}_{2} \mathrm{O}_{5}$, dicalcium dialuminate.

Shock metamorphism and micro-impacts: planar deformation features (PDF) in moissanite; open, tensile spallation fractures in titanium carbide crystals; cosmic particle impacts (Fig. 3).

\section{Conclusion}

Enigmatic internal structures and exotic composition for all sizes of iron silicide samples from the Chiemgau impact crater strewn field establish a common formation process and a common source.

Artificial production, geogenic formation (and e.g. fulgurite formation) can be excluded, which is basically also supported by the find situations in the field $[1,2]$. The iron silicides are of extraterrestrial origin.

The iron silicides in their entity belong to the Chiemgau meteorite impact strewn field.

They should constitute a new class of meteorites. For reasons of definiteness we suggest to name the trigonal $\mathrm{Fe}_{2} \mathrm{Si}$ polymorph hapkeite $-2 \mathrm{~T}$ possibly rating a new mineral name [2].

\section{References}

1. Rappenglück, M. A., Rappenglück, B. \& Ernstson. K. Kosmische Kollision in der Frühgeschichte. Der Chiemgau-Impakt: Die Erforschung eines bayerischen Meteoritenkrater-Streufelds //Zeitschrift für Anomalistik. 2017. V. 17. P. 235-260 (English translation in [2]).

2. Rappenglück, M. A., Rappenglück, B. \& Ernstson. K. Cosmic collision in prehistory. - The Chiemgau Impact: research in a Bavarian meteorite crater strewn field // Zeitschrift für Anomalistik. 2017. V 17. P. 235260. http://www.impaktstrukturen.de/wp-content/uploads/2018/11/Anomalisten-translation.pdf.

3. Bauer, F., Hiltl, M., Rappenglück, M. A., Ernstson, K. Trigonal and cubic Fe2Si polymorphs (hapkeite) in the eight kilograms find of natural iron silicide from Grabenstätt (Chiemgau, Southeast Germany)// 50th Lunar and Planetary Science Conference. The Woodlands, LPI. 2019, abstract 1520.pdf. 